\title{
Molecular characterization of Clostridium difficile clinical isolates in a geriatric hospital
}

Correspondence
Anne Collignon
anne.collignon@jvr.ap-hop-paris.fr

Received 4 March 2006

Accepted 8 September 2006

\author{
Isabelle Poilane, ${ }^{1}$ Christel Humeniuk-Ainouz, ${ }^{1}$ Isabelle Durand, ${ }^{1}$ \\ Claire Janoir, ${ }^{2}$ Philippe Cruaud, ${ }^{1}$ Michel Delmée, ${ }^{3}$ Michel R. Popoff ${ }^{4}$ \\ and Anne Collignon ${ }^{1,2}$ \\ ${ }^{1}$ AP-HP, Hôpital Jean Verdier-René Muret, Service de Microbiologie, Bondy, France \\ 2Université de Paris-Sud-XI, Faculté de Pharmacie, USC INRA EA3534, Châtenay-Malabry, \\ France \\ ${ }^{3}$ Université Catholique de Louvain, Unité de Microbiologie, Brussels, Belgium \\ ${ }^{4}$ Institut Pasteur, Unité des Bactéries Anaérobies et du Botulisme, Paris, France
}

The discriminatory potential of a combination of various typing methods was evaluated on a set of 21 Clostridium difficile isolates obtained from symptomatic patients hospitalized in a geriatric unit and 7 non-toxigenic isolates from the same hospital. Isolates were firstly serotyped and toxinotyped. Of the 28 isolates, 19 belonged to serogroup A. PCR-ribotyping and PCR-RFLP on the fliC and $s / p A$ genes were then applied to these 19 isolates. The results suggest that the combination of PCR-ribotyping with PCR-RFLP analysis of $s / p A$ could be more discriminatory and suitable for studying C. difficile epidemiology.

\section{INTRODUCTION}

Clostridium difficile is recognized as the main enteric pathogen involved in nosocomial diarrhoea. Many risk factors have been identified, including antibiotic treatment, duration of hospital stay, increasing age and underlying diseases (Bignardi, 1998). Consequently, elderly patients hospitalized in long-stay units are particularly susceptible to developing $C$. difficile-associated disease. Many typing methods have been evaluated for $C$. difficile epidemiological studies (Brazier, 2001). Phenotypic methods are mainly based on serogrouping (Delmée et al., 1985), which determined 10 major serogroups (A, B, C, D, F, G, H, I, $\mathrm{K}$ and $\mathrm{X}$ ) and 20 subserogroups in group $\mathrm{A}$ (A1-A20). Genotyping has also been developed for studying C. difficile. Toxinotyping is based on the polymorphisms observed in both toxin genes $t c d A$ and $t c d B$ (Rupnik et al., 1998). Arbitrarily primed PCR, PFGE and PCR-ribotyping have been applied to $C$. difficile strains with success (Gal et al., 2005; Wullt et al., 2003). PCR-ribotyping has been widely used and offers good typeability, reproducibility and discriminatory power. In the UK, Stubbs et al. (1999) applied this method to 2030 strains and differentiated 116 PCR-ribotypes.

Other typing methods have been proposed for $C$. difficile. Tasteyre et al. (2000) studied the variability of the flagellin $f l i C$ gene and compared the RFLP groups to serogroups of 10 reference strains. They described a good correlation between the two methods and proposed PCR-RFLP on the fliC gene as an additional typing method. Previous reports have also described the variability of the S-layer protein (SlpA) among C. difficile isolates (Calabi et al., 2001; Kato et al., 2005; McCoubrey et al., 2003). Karjalainen et al. (2002) suggested that genotyping based on slpA gene studies could be useful for typing strains. DNA and deduced amino acid sequences of the $\operatorname{slp} A$ variable region were $100 \%$ identical within a given serogroup whereas variability appeared greater among subserogroup A strains. The subserogroup specificity of highly flagellated serogroup A could be attributable to the flagella. Consequently, these PCR-RFLP methods could be of interest for subtyping.

The aim of this study was to characterize by various typing methods $C$. difficile isolates from a population of elderly patients hospitalized in a geriatric hospital in order to better understand the local $C$. difficile epidemiology. We used serotyping and toxinotyping first to discriminate the $C$. difficile isolates. We then applied PCR-ribotyping and PCRRFLP analysis of the $\operatorname{slpA}$ and fliC genes to the serogroup A isolates in order to test these methods with clinical isolates.

\section{METHODS}

Clinical isolates and reference strains. Twenty-one $C$. difficile isolates were obtained over a period of 12 months (November 2001November 2002) from symptomatic patients with a diagnosis of $C$. difficile-associated disease on the basis of a positive $C$. difficile culture, and toxin $\mathrm{A}$ and $\mathrm{B}$ detection. These patients were hospitalized in a long-stay hospital (René Muret Hospital, Assistance PubliqueHôpitaux de Paris, Sevran, France). In addition, seven non-toxigenic 
isolates from the same hospital and two reference strains of specific group A (ATCC 43594 and TO005 for serogroups A1 and A10, respectively) were also analysed as unrelated control strains.

Serogrouping. The serogroup of each strain was determined as previously described by Delmée et al. (1985).

Toxinotyping. DNA was extracted from $1 \mathrm{ml}$ of an overnight anaerobic culture (Trypticase Glucose Yeast broth) using the protocol provided in the Instagene kit (Bio-Rad). Genetic identification of $t c d A$ and $t c d B$ profiles was determined by the PCR method described by Rupnik et al. (1998). Fragments A1, A2 and A3 and B1, B2 and B3 were amplified, and fragments B1 and A3 were digested by HincII or AccI and by EcoRI or SpeI, respectively. The profiles were compared to those described by Rupnik et al. (1998).

DNA preparation for PCR-typing. DNA templates were prepared from $48 \mathrm{~h}$ anaerobic cultures with the PSP Spin Swab kit (Invitek) according to the manufacturer's instructions. PCR amplification of target DNA was performed using PuRe Taq Ready-to-Go PCR tubes (Amersham). PCR was carried out in a PTC 200 thermocycler (MJ Research).

PCR-ribotyping. This method was performed according to Bidet et al. (1999). The primer sequences (16S primers) were 5'-GTGCGGCTGGATCACCTCCT-3' and 5'-CCCTGCACCCTTAATAACTTGACC-3'. Initial denaturation was carried out for one cycle of $5 \mathrm{~min}$ at $94{ }^{\circ} \mathrm{C}$ followed by 35 cycles of $1 \mathrm{~min}$ at $94{ }^{\circ} \mathrm{C}, 1 \mathrm{~min}$ at $57^{\circ} \mathrm{C}$ and $1 \mathrm{~min}$ at $72{ }^{\circ} \mathrm{C}$, and a final extension for $7 \mathrm{~min}$ at $72^{\circ} \mathrm{C}$. Amplified products were analysed by electrophoresis on a $2 \%$ agarose gel (Eurobio) for $2 \mathrm{~h}$ at $85 \mathrm{~V}$.

PCR-RFLP. The variability of the fliC gene encoding flagellin was studied by PCR-RFLP. The primer sequences were 5'-ATGAGAGTTAATACAAATGTAAGTGC- $3^{\prime}$ and $5^{\prime}$-CTATCCTAATAATTGTAAAACTCC- $3^{\prime}$. Initial denaturation was carried out at $95^{\circ} \mathrm{C}$ for $5 \mathrm{~min}$ followed by 35 cycles of $94{ }^{\circ} \mathrm{C}$ for $30 \mathrm{~s}, 55^{\circ} \mathrm{C}$ for $30 \mathrm{~s}$ and $72{ }^{\circ} \mathrm{C}$ for $1 \mathrm{~min}$, followed by a final extension at $72^{\circ} \mathrm{C}$ for $10 \mathrm{~min}$. Amplified products were digested with the restriction enzymes HindIII, DraI, RsaI and HinfI. The digested amplified products were analysed by electrophoresis in a $2 \%(\mathrm{w} / \mathrm{v})$ agarose gel with a $100 \mathrm{bp}$ ladder (Eurobio) as the molecular size marker (Tasteyre et al., 2000).

The variable domain of the $\operatorname{slp} A$ gene encoding the $S$ layer was amplified. The primer sequences were $5^{\prime}$-ATGAATAAGAAAAAYWTAGCAATRGC-3' and 5'-TCTATTCTATCTTCTCCWGCTAC-3'. Initial denaturation was carried out at $95^{\circ} \mathrm{C}$ for 5 min followed by 35 cycles of $95^{\circ} \mathrm{C}$ for $30 \mathrm{~s}, 45^{\circ} \mathrm{C}$ for $1 \mathrm{~min}$ and $72^{\circ} \mathrm{C}$ for $1 \mathrm{~min}$, followed by a final extension at $72{ }^{\circ} \mathrm{C}$ for $10 \mathrm{~min}$. Amplified products were digested with the restriction enzymes PvuII, Hinfl, DraI and RsaI. The digested amplified products were analysed by electrophoresis in a $2 \%$ (w/v) agarose gel with a $100 \mathrm{bp}$ ladder (Eurobio) as the molecular size marker (Karjalainen et al., 2002).

\section{RESULTS AND DISCUSSION}

Among the 28 isolates studied, 19 belonged to serogroup A, three to serogroup K, two to serogroup G, two to serogroup $\mathrm{H}$, one to the non-toxigenic serogroup $\mathrm{D}$ and one isolate was non-typeable. Among the serogroup A isolates, 16 were toxigenic (toxin $A$ and $B$ positive) and all were toxinotype 0 . These results are in accordance with other studies that reported the high frequency of toxinotype 0 among clinical isolates (Geric et al., 2004). No isolate belonged to the hypertoxigenic toxinotype III recently described in North America (Loo et al., 2005).
All the serogroup A isolates were tested by PCR-ribotyping and yielded seven different PCR-ribotypes. The most common PCR-ribotype 1 contained 10 isolates. PCRribotype 2 was identified for three isolates, PCR-ribotype 3 for two isolates and the PCR-ribotypes 4-7 for one isolate each. All isolates were typeable and all PCR-ribotype 1 isolates were toxigenic. The non-toxigenic isolates of this serogroup belonged to the PCR-ribotypes 3 and 5 (Table 1). PCR-ribotyping displayed good typeability and good discriminatory power, as suggested by numerous studies using PCR-ribotyping (in association with other typing methods) to study outbreaks due to C. difficile (Fawley et al., 2005; Warny et al., 2005).

For RFLP analysis of the $f l i C$ gene, the amplified product (870 bp) was digested with four endonucleases. For each endonuclease, two patterns were identified (Fig. 1). The combination of these patterns allowed us to classify the isolates into two profiles, I and VII, according to Tasteyre et al. (2000). Eighteen isolates gave profile VII as did the reference strain A1; only one isolate displayed profile I (Table 1). All isolates were typeable. Tasteyre et al. (2000) showed that flagellin gene PCR-RFLP analysis could constitute an additional typing method. In their study of 47 C. difficile isolates, this method discriminated nine different RFLP groups (I-IX). In our study, we chose endonucleases that offered, according to these authors, the best discriminatory power among serogroup A isolates. However, compared to PCR-ribotyping, it appeared less discriminatory for serogroup A isolates.

For the $\operatorname{slp} A$ gene, the amplified product $(\sim 1000 \mathrm{bp})$ was digested with four endonucleases. Four patterns were identified with the endonucleases HinfI, PvuII and DraI and only three with RsaI (Fig. 2). The combination of these patterns allowed us to distinguish four different profiles, 1 , 2, 3 and 4, among the isolates. However, nine isolates were not typeable under our PCR conditions (Table 1). It has already been reported that $C$. difficile surface proteins display a high variability (Péchiné et al., 2005). McCoubrey et al. (2003) studied the variation in the molecular mass of the $C$. difficile S-layer proteins and identified seven $S$ types among 100 isolates. The $C$. difficile $S$ layer is composed of two proteins of variable size: a higher-molecular-mass protein of $48-56 \mathrm{kDa}$ encoded by the conserved $3^{\prime}$-terminal part of the $\operatorname{slp} A$ gene and a lower-molecular-mass protein of $36-45 \mathrm{kDa}$ encoded by the variable $5^{\prime}$-terminal part of the gene. The lower-molecular-mass S-layer protein (P36 protein) is located on the exterior surface of the bacteria and exhibits a high degree of variability. Karjalainen et al. (2002) suggested that genotyping based on this variable domain of the $\operatorname{slp} A$ gene could be useful for typing. They showed that the gene could be easily amplified from various strains of different serogroups and that this PCR-RFLP typing method associated with DNA sequencing of the $\operatorname{slp} A$ variable region could constitute an alternative method for determining $C$. difficile serogroups. Since the $\operatorname{slp} A$ sequences were quite similar in serogroups $\mathrm{A} 1$ and A10, the 20 
Table 1. Epidemiological study of Clostridium difficile serogroup A isolates from elderly patients by different typing methods

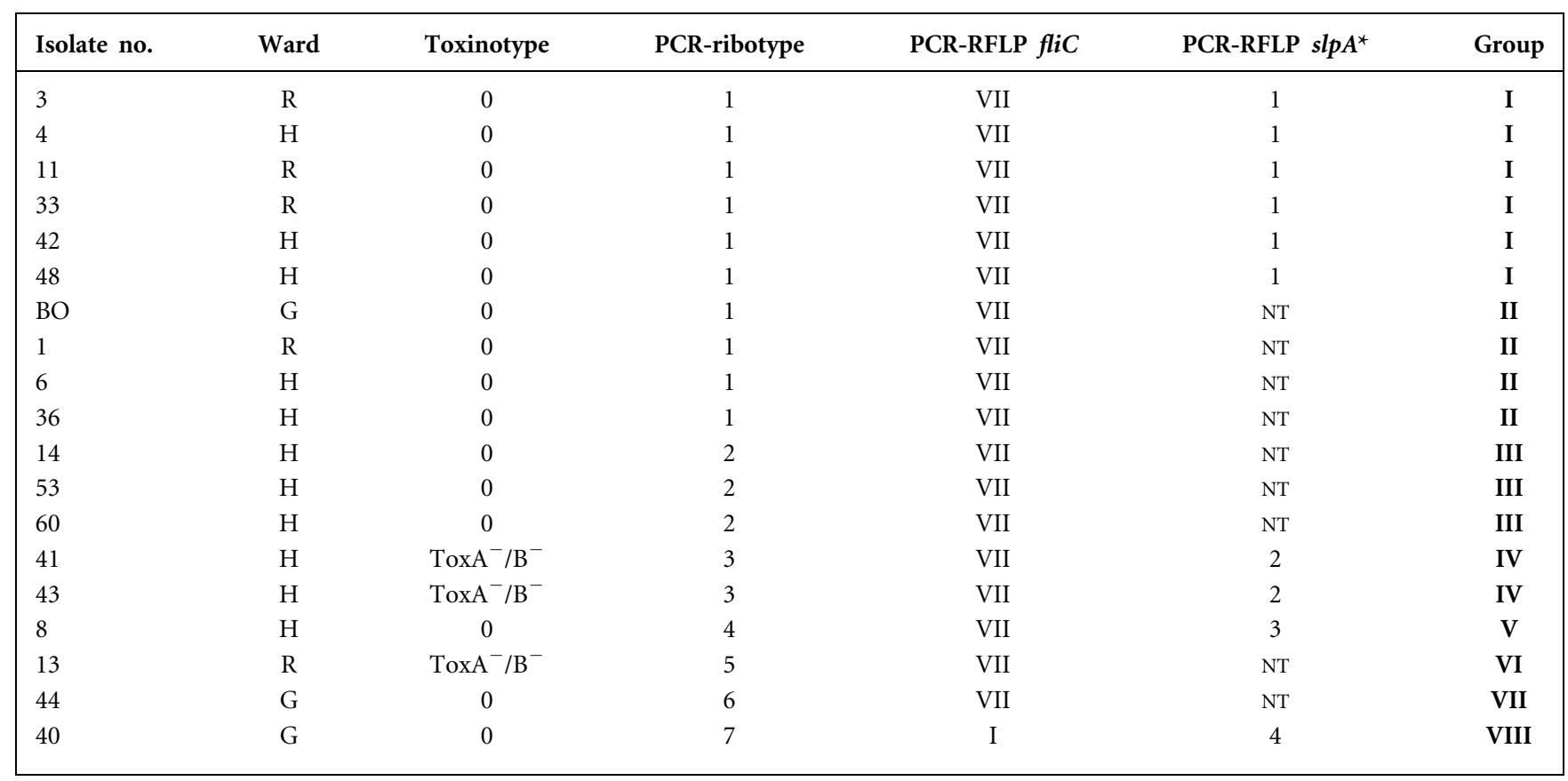

${ }^{\star}$ NT, Non-typeable.

subserogroups of serogroup A may not be completely specified by using this method. In our study, serogroup A isolates were classified into four groups and an additional group of non-typeable isolates. This suggests a high variability of the $\operatorname{slp} A$ gene in serogroup $\mathrm{A}$. To enhance

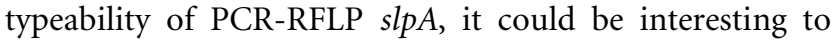
choose primers in more conserved regions. Kato et al. (2005) used nested PCR with two pairs of primers chosen in a conserved region of the slpA gene for $C$. difficile typing by sequencing the $\operatorname{slp} A$ gene. All the strains were typeable, and sequences could be compared among different laboratories from a database. However, as sequence analysis is not always available in clinical laboratories, we studied the discriminatory power and the typeability of PCR-RFLP on the $\operatorname{slp} A$

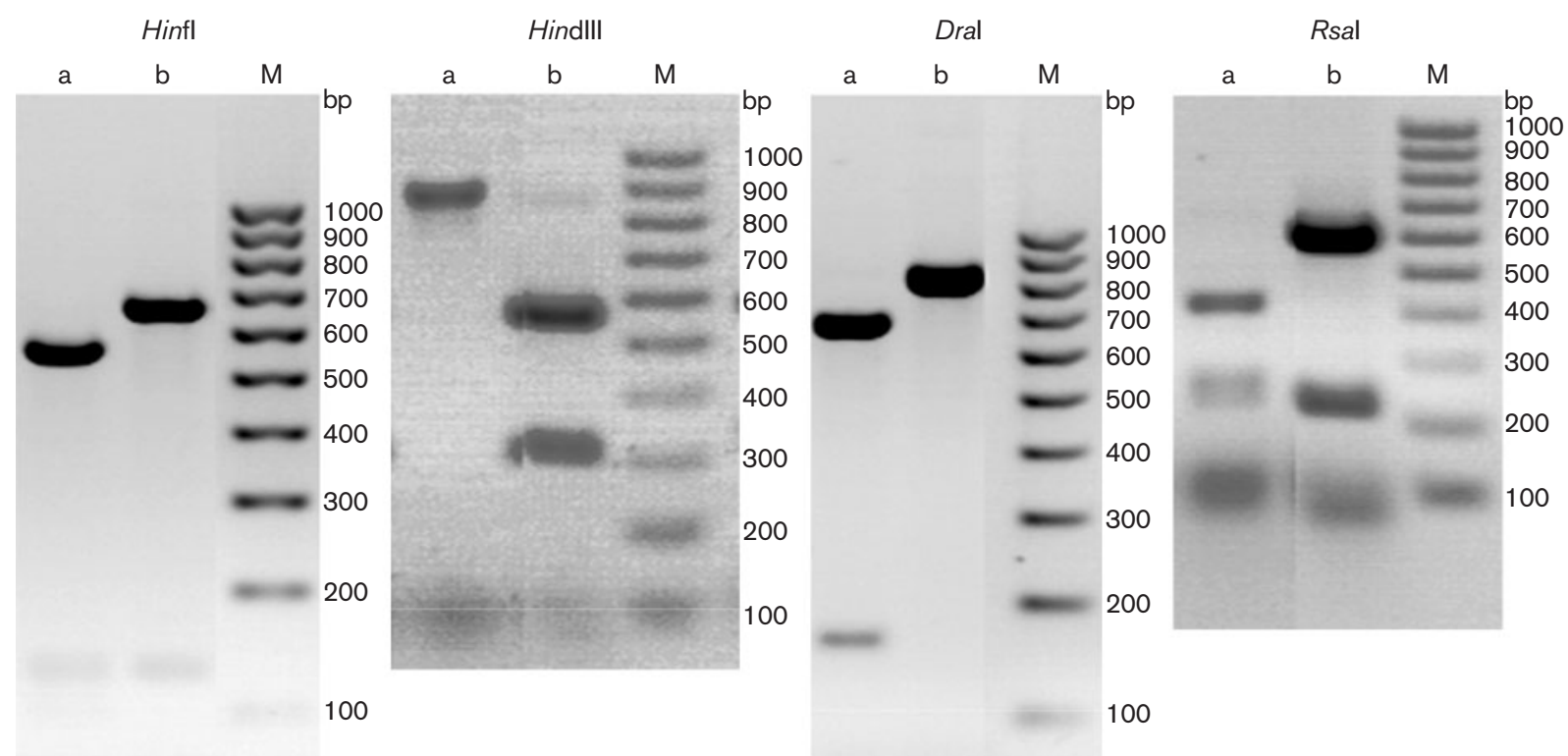

Fig. 1. RFLP patterns of the PCR-amplified fliC gene: two patterns, a and b, were obtained with each enzyme. Lanes $M$, $100 \mathrm{bp}$ ladder (Eurobio). 

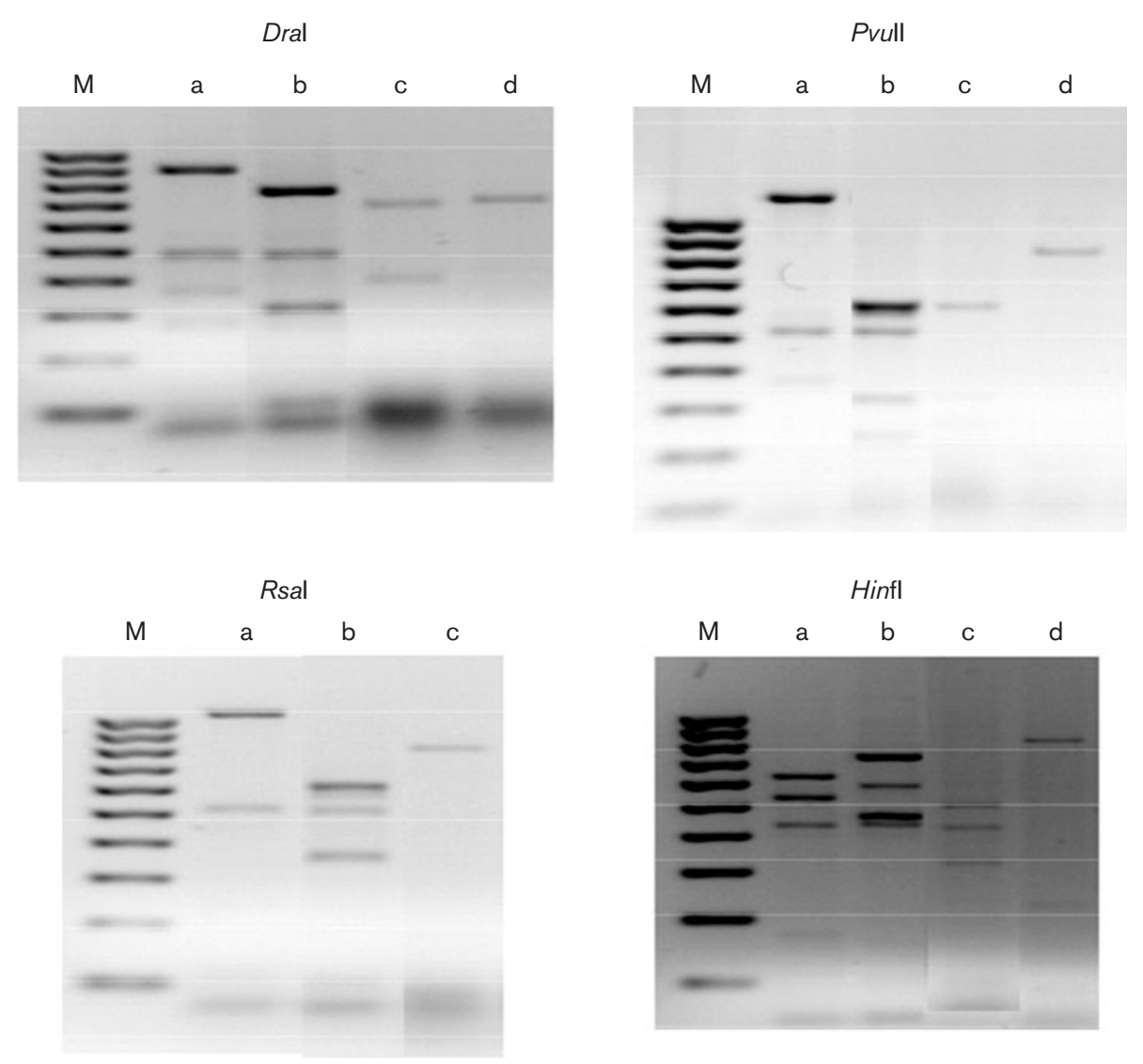

Fig. 2. RFLP patterns of the PCR-amplified $s / p A$ gene: four patterns, a, b, c and d, were obtained with Dral, Pvull and Hinfl, and three patterns, a, b and c, with Rsal. Lanes M, 100 bp ladder (Eurobio).

gene, which is a more practicable method. The variability of slpA and fliC genes has been confirmed by multilocus sequence analysis, demonstrating that these genes underwent recombination events under environmental selective pressure (Lemée et al., 2005).

Considering all these typing methods, the 19 serogroup A isolates were distributed among eight main groups (I-VIII), demonstrating the circulation of different strains in the hospital (Table 1). The toxigenic serogroup A isolates belonged to groups I, II, III, IV, VII and VIII whereas the non-toxigenic isolates belonged to two other groups, IV and VI. Six isolates belonging to group I were found to be closely related by PCR-ribotyping and PCR-RFLP slpA. The PCRRFLP slpA analysis allowed for the subdivision of PCRribotype 1 into two groups.

In conclusion, PCR-ribotyping combined with PCR-RFLP analysis of the $s l p A$ gene appears to be more discriminatory than PCR-ribotyping alone. These methods are suitable for investigating C. difficile cross-infections and understanding the epidemiology of this enteropathogen in geriatric units. They showed the spread of three main clones among toxigenic serogroup $\mathrm{A}$ isolates and the persistence of a group I strain over 11 months in two wards of the hospital. This may have been due to transmission from patient to patient or from environment to patients. Spores may have played a main role in cross-infection.

\section{REFERENCES}

Bidet, P., Barbut, F., Lalande, V., Burghoffer, B. \& Petit, J. C. (1999). Development of a new PCR-ribotyping method for Clostridium difficile based on ribosomal RNA gene sequencing. FEMS Microbiol Lett 175, 261-266.

Bignardi, G. E. (1998). Risk factors for Clostridium difficile infection. J Hosp Infect 40, 1-15.

Brazier, J. S. (2001). Typing of Clostridium difficile. Clin Microbiol Infect 7, 428-431.

Calabi, E., Ward, S., Wren, B., Paxton, T., Panico, M., Morris, H., Dell, A., Dougan, G. \& Fairweather, N. (2001). Molecular characterization of the surface layer proteins from Clostridium difficile. Mol Microbiol 40, 1187-1199.

Delmée, M., Homel, M. \& Wauters, G. (1985). Serogrouping of Clostridium difficile strains by slide agglutination. J Clin Microbiol 21, 323-327.

Fawley, W. N., Parnell, P., Verity, P., Freeman, J. \& Wilcox, M. H. (2005). Molecular epidemiology of endemic Clostridium difficile infection and the significance of subtypes of the United Kingdom epidemic strain (PCR Ribotype 1). J Clin Microbiol 43, 2685-2696. 
Gal, M., Northey, G. \& Brazier, J. S. (2005). A modified pulsed-field gel electrophoresis (PFGE) protocol for subtyping previously nonPFGE typeable isolates of Clostridium difficile polymerase chain reaction ribotype 001. J Hosp Infect 61, 231-236.

Geric, B., Rupnik, M., Gerding, D. N., Grabnar, M. \& Johnson, S. (2004). Distribution of Clostridium difficile variant toxinotypes and strains with binary toxin genes among clinical isolates in an American hospital. J Med Microbiol 53, 887-894.

Karjalainen, T., Saumier, N., Barc, M. C., Delmée, M. \& Collignon, A. (2002). Clostridium difficile genotyping based on slpA variable region in S-layer gene sequence: an alternative to serotyping. J Clin Microbiol 40, 2452-2458.

Kato, H., Yokoyama, T. \& Arakawa, Y. (2005). Typing by sequencing the slpA gene of Clostridium difficile strains causing multiple outbreaks in Japan. J Med Microbiol 54, 167-171.

Lemée, L., Bourgeois, I., Ruffin, E., Collignon, A., Lemeland, J. F. \& Pons, J. L. (2005). Multilocus sequence analysis and comparative evolution of virulence-associated genes and housekeeping genes of Clostridium difficile. Microbiology 151, 3171-3180.

Loo, V. G., Poirier, L., Miller, M. A., Oughton, M., Libman, M. D., Michaud, S., Bourgault, A. M., Nguyen, T., Frenette, C. \& other authors (2005). A predominantly clonal multi-institutional outbreak of Clostridium difficile-associated diarrhea with high morbidity and mortality. N Engl J Med 353, 2442-2449.

McCoubrey, J., Starr, J., Martin, H. \& Poxton, I. R. (2003). Clostridium difficile in a geriatric unit: a prospective epidemiological study employing a novel S-layer typing method. J Med Microbiol 52, 573-578.

Péchiné, S., Gleizes, A., Janoir, C., Gorges-Kergot, R., Barc, M. C., Delmée, M. \& Collignon, A. (2005). Immunological properties of surface proteins of Clostridium difficile. J Med Microbiol 54, 1-4.

Rupnik, M., Avesani, V., Janc, M., von Eichel-Streiber, C. \& Delmée, M. (1998). A novel toxinotyping scheme and correlation of toxinotypes with serogroups of Clostridium difficile isolates. J Clin Microbiol 36, 2240-2247.

Stubbs, S. L. J., Brazier, J. S., O’Neill, G. L. \& Duerden, B. I. (1999). PCR targeted to the 16S-23S rRNA gene intergenic spacer region of Clostridium difficile and construction of a library consisting of 116 different PCR ribotypes. J Clin Microbiol 37, 461-463.

Tasteyre, A., Karjalainen, T., Avesani, V., Delmée, M., Collignon, A., Bourlioux, P. \& Barc, M. C. (2000). Phenotypic and genotypic diversity of the flagellin gene (fliC) among Clostridium difficile isolates from different serogroups. J Clin Microbiol 38, 3179-3186.

Warny, M., Pepin, J., Fang, A., Killgore, G., Thompson, A., Brazier, J., Frost, E. \& McDonald, L. C. (2005). Toxin production by an emerging strain of Clostridium difficile associated with outbreaks of severe disease in North America and Europe. Lancet 366, 1079-1084.

Wullt, M., Burman, L. G., Laurell, M. H. \& Akerlund, T. (2003). Comparison of AP-PCR typing and PCR-ribotyping for estimation of nosocomial transmission of Clostridium difficile. J Hosp Infect 55, $124-130$. 